\title{
Conflicts in South Asia - Challenges to SAARC Regionalism
}

\author{
Dr. Sunita Pachori \\ Department of Geography, SPC Government College, Ajmer (Raj) India
}

"Corresponding Author: Dr. Sunita Pachori, Department of Geography, SPC Government College, Ajmer (Raj) India.

\section{INTRODUCTION}

Richness in material and human resources has warranted a constant interaction between countries in South Asia and the outside world. South Asian states have also been aware of their geopolitical advantages and need to integrate into a regional force. Efforts were made earlier ${ }^{1}$ to create institutional mechanisms for regional integration in order to enable the fostering of a common regional identity and a cooperative growth strategy making optimum use of inter-regional trade and social and political development. A culmination of such an understanding was the creation of the South Asian Association for Regional Cooperation (SAARC).

The South Asian region currently faces a grave security threat due to increasing extremism and terrorist activities. The politics of violence and extremist trends in South Asia can be linked to the contradictions arising as a consequence of faulty national policies. The South Asian states tend to operate in the interests of a coalition of classes and ethnic groups, thereby influencing development policies and the distribution of resources. The pace, content and dynamics of the uneven development patterns in South Asia are among the predominant causes of violence in the region. Terrorism and the rise of extremism has been occurring in South Asia for a variety of reasons, including perpetration by tyrannical and aggressive regimes and rebel groups, social injustice, ideological contradictions, religious beliefs and foreign interference. However, deteriorating socio-economic conditions, government policies and outside interference in all South Asian countries have been the primary factors responsible for the rise of extremism in the region. Terrorism and its political consequences have directly and visibly affected interstate relations in South Asia and have also led to destabilization in the region.

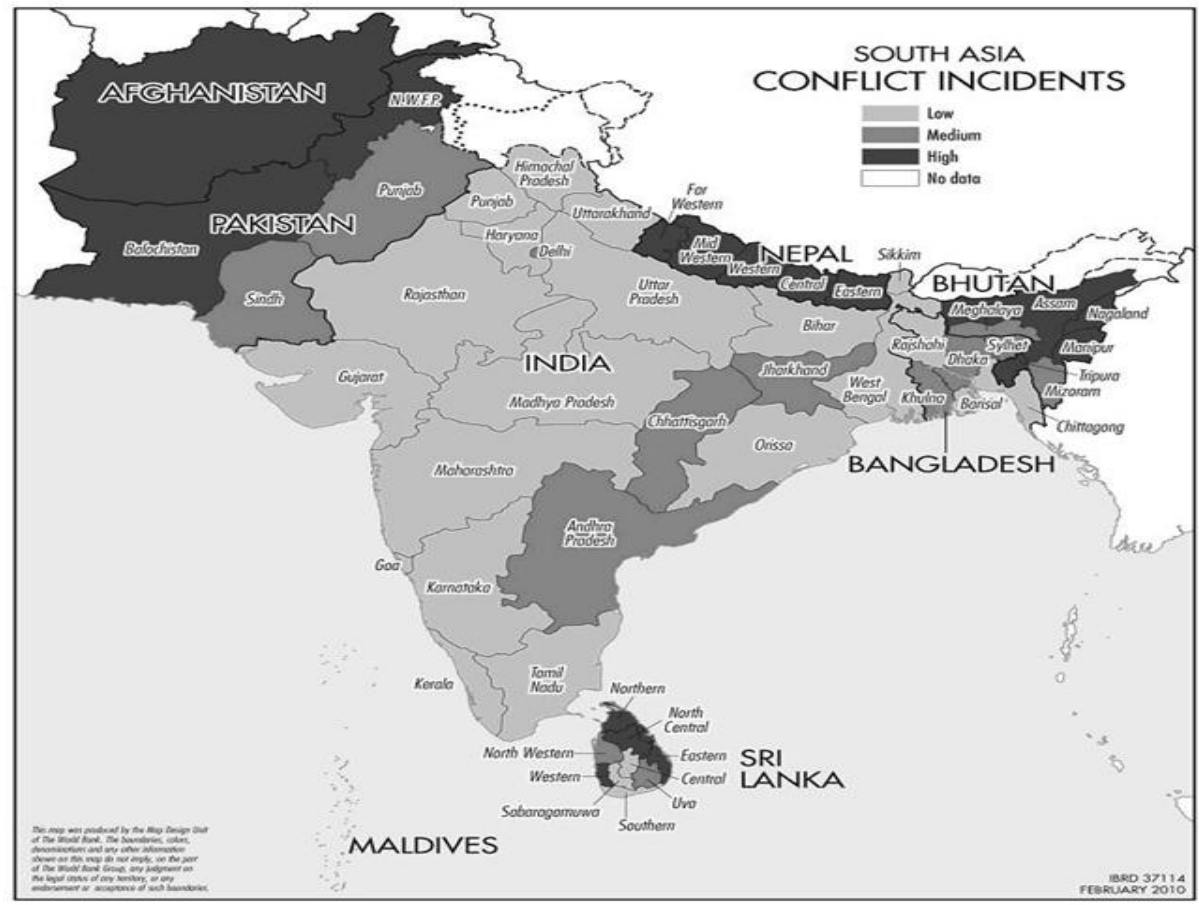

Map1: South Asian Countries 
While South Asia had never been a coherent geopolitical region, it has a distinct geographical identity Map1. Shows that in India, Bangladesh, Nepal, Pakistan, and Sri Lanka, conflict is concentrated in the lagging regions. Conflict rates are higher in the lagging regions of Pakistan (Baluchistan, Federally Administered Tribal Areas, and North-West Frontier Province), India (Maoist insurgency in Bihar, Chhattisgarh, Jharkhand, and Orissa), Sri Lanka (North), and Nepal. Lagging regions have experienced more than three times the number of terrorist incidents per capita, compared with leading regions, and almost twice as many deaths per head of population in such incidents.

Created in 1985, SAARC follows the principles of: focus on social and economic matters; decisions by consensus; and non-discussion on contentious bilateral issues. According to the SAARC Charter (1985) member states are 'desirous of peace, stability, amity and progress in the region through strict adherence to the principles of the United Nations Charter and Non-Alignment, particularly, respect for the principles of sovereign equality, territorial integrity, national independence, non-use of force and non-interference in the internal affairs of other States and peaceful settlement of all disputes'. This charter was signed by heads of states of Bangladesh, Bhutan, India, Maldives, Nepal, Pakistan and Sri Lanka, in 1985 in Dhaka. Over the years, SAARC has attempted to address several regional concerns, for instance, drugs and human trafficking, economic cooperation among south Asian states and the forging of a south Asian social identity, and most recently efforts have been made to tackle the menace of terrorism in the region. 'Regionalism' has a different meaning and purpose for each nation when they become a part of any regional organization. In most cases, states that join hands in any regional cooperation mechanism have certain basic differences; for most, regional cooperation is limited only to economic cooperation through free-trade agreements. Differences among member states of the regional cooperation organizations are greater in the presence of inter-state conflicts between the member states. Even if states seem to agree on some issues at the platform of that particular regional cooperation organization, their intentions behind the concept and purpose of regionalism are fundamentally different. Inter-state conflicts have posed hurdles to regionalism. This phenomenon is clearly visible in the functioning of the SAARC. The Geographical factors which favor insurgency, economic factors such as poverty, social diversity, and also institutional factors, such as poor property rights. Nation level regressions for SAARC show a strong correlation between the incidence of poverty and the intensity of conflict, over and above the impact of geographical factors like altitude or the presence of hills and forests. This is consistent with the trend of rising conflict in lagging areas, and provides further evidence of the link between economic backwardness and violence.

\section{DATA}

Any empirical analysis of terrorism or conflict is complicated by data constraints. First, there are long-running separatist movements in SARRC countries (Bangladesh, India, Bhutan, Pakistan and Sri Lanka);

Table1: Types of conflict between the member states of SAARC

\begin{tabular}{|c|c|}
\hline \multicolumn{2}{|l|}{ Territorial conflicts } \\
\hline SAARC members & Conflict \\
\hline India-Pakistan & Deadlock on issues of Siachen \\
\hline & $\begin{array}{l}\text { glacier, Kargil and Sir Creek. } \\
\text { Kashmir dispute which has resulted in two major wars }\end{array}$ \\
\hline Afghanistan-Pakistan & Durand line issue \\
\hline \multicolumn{2}{|l|}{ Cross-border terrorism } \\
\hline SAARC members & Conflict \\
\hline India-Pakistan & $\begin{array}{l}\text { On several occasions there have been blames from both sides (India } \\
\text { and Pakistan) on each other for carrying out terrorist activities or } \\
\text { supporting such acts in their country. }\end{array}$ \\
\hline India-Bangladesh & Illegal immigration of Bengalis into India. \\
\hline Afghanistan-Pakistan & $\begin{array}{l}\text { Pakistan has decided to shut down refugee camps under increasing } \\
\text { pressure to crack down on cross-border militancy. }\end{array}$ \\
\hline 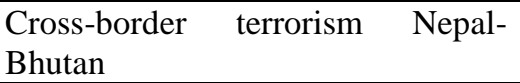 & Over repatriation of Bhutanese refugees in Nepal. \\
\hline
\end{tabular}


The second source of internal violence in South Asia comes from incidents perpetrated by extremist groups ("Naxalite" movements) in many countries of South Asia. The geographical spread of such groups has been rising in recent years in 2007.

The third source of increasing violence in South Asia stems from incidents of terrorism in SAARC countries. Such incidents, typically the use of bombs in crowded locations, have been on the rise. In recent years, there have been several instances of multiple coordinated bomb blasts in South Asia

Table2: Conflict over natural resources

\begin{tabular}{|l|l|}
\hline \multicolumn{1}{|c|}{ SAARC members } & \multicolumn{1}{c|}{ Conflict } \\
\hline India-Pakistan & $\begin{array}{l}\text { Both countries are having dialogue regarding the Baglihar dam being built } \\
\text { over River Chenab in Indian-administered Kashmir. }\end{array}$ \\
\hline India-Bangladesh & $\begin{array}{l}\text { Bangladesh wants a fair share of Ganga river by opposing the construction of } \\
\text { Farrakha Barrage in India }\end{array}$ \\
\hline
\end{tabular}

Table3: South Asia Fatalities 2010-2017

\begin{tabular}{|l|l|l|l|l|}
\hline Years & Civilians & SFs(Security Forces) & Terrorists & Total \\
\hline 2010 & 2571 & 844 & 6016 & 9431 \\
\hline 2011 & 3173 & 962 & 3284 & 7419 \\
\hline 2012 & 3270 & 871 & 2902 & 7043 \\
\hline 2013 & 3536 & 887 & 2244 & 6667 \\
\hline 2014 & 2217 & 703 & 3631 & 6551 \\
\hline 2015 & 1144 & 496 & 2837 & 4477 \\
\hline 2016 & 854 & 476 & 1505 & 2835 \\
\hline 2017 & 533 & 249 & 663 & 1445 \\
\hline Total & & & & \\
\hline
\end{tabular}

* Data till August 6, 2017

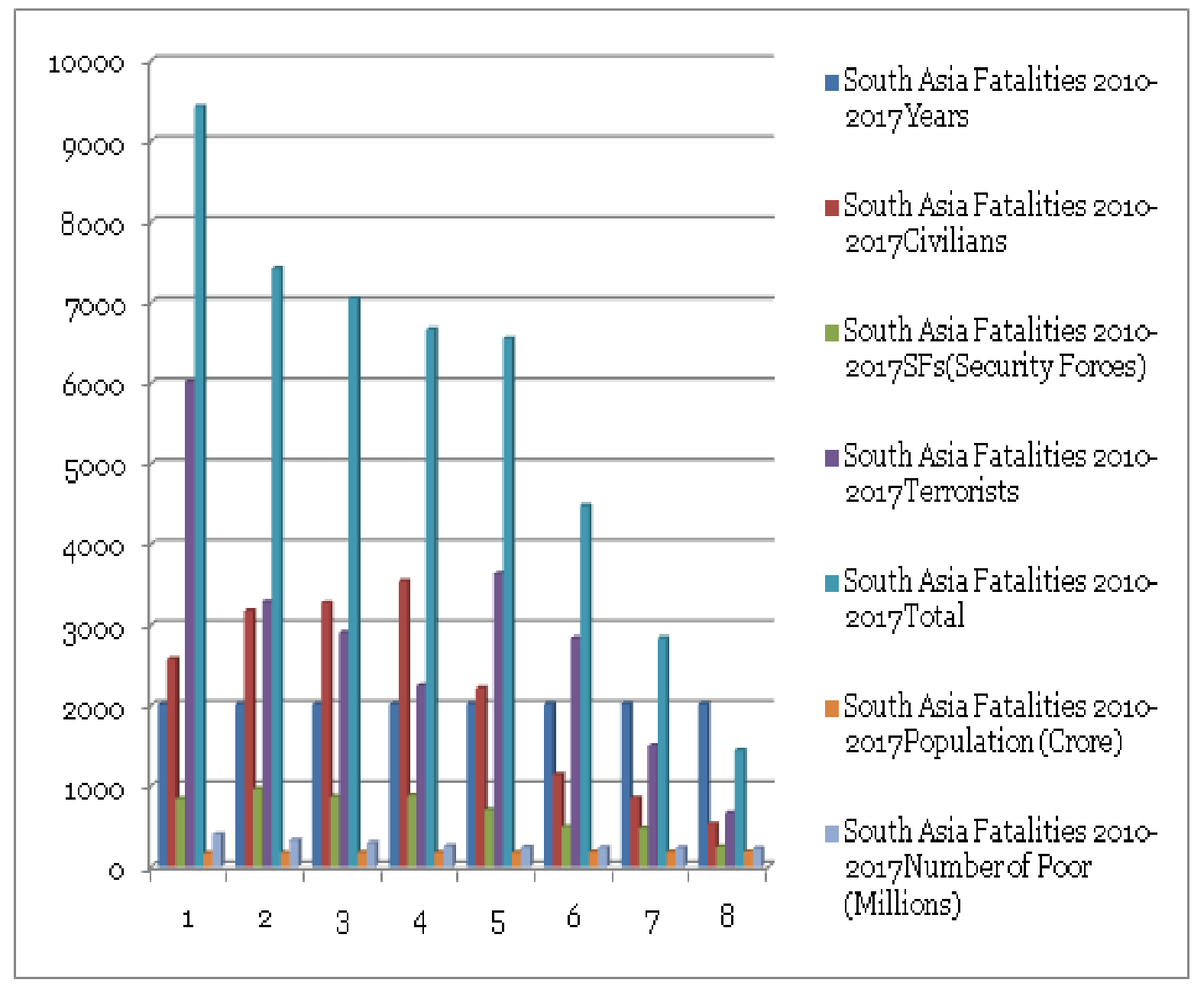




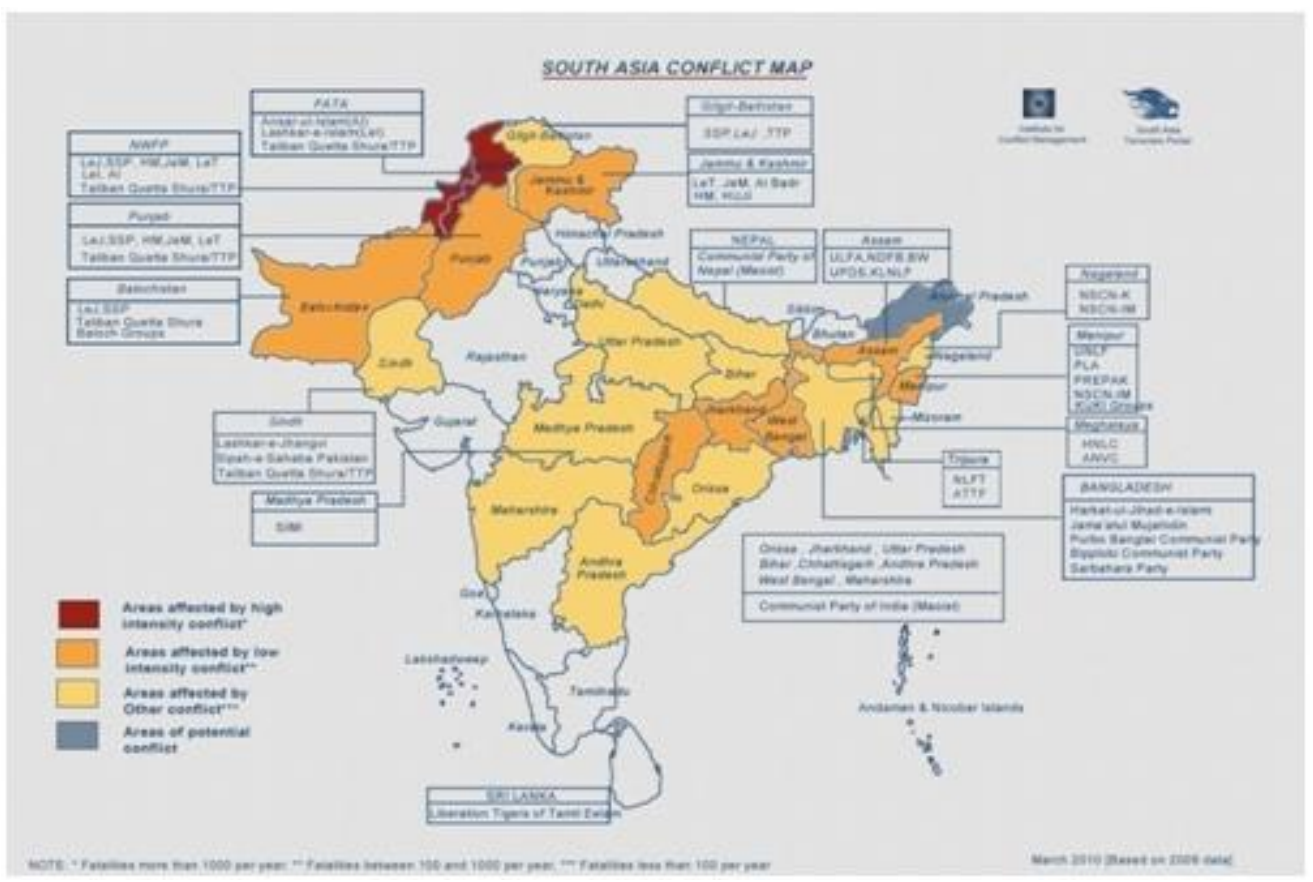

Map2: South Asia Conflicts 2010

SOUTH ASIA CONFLICTS 2012

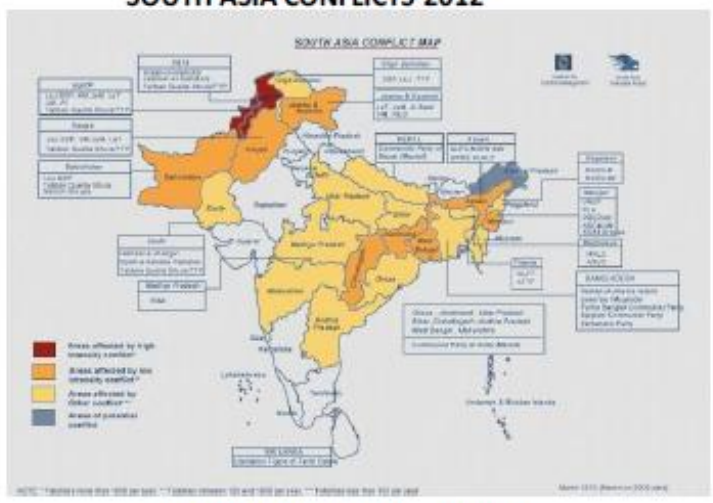

SOUTH ASIA CONFLICTS IN 2014

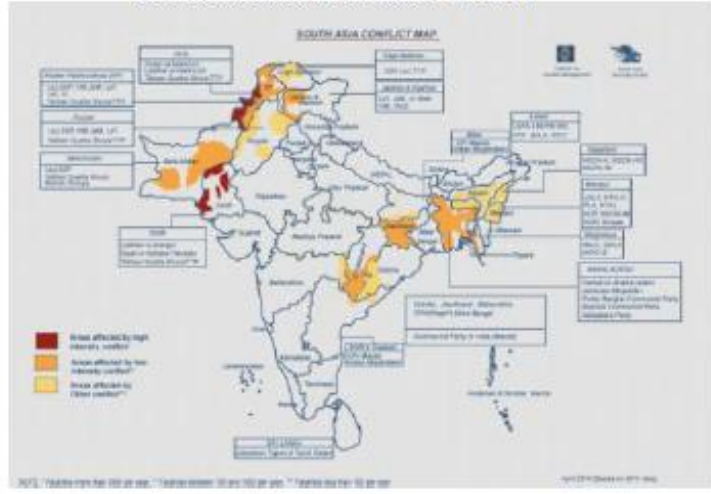

SOUTH ASIA CONFLICTS 2011

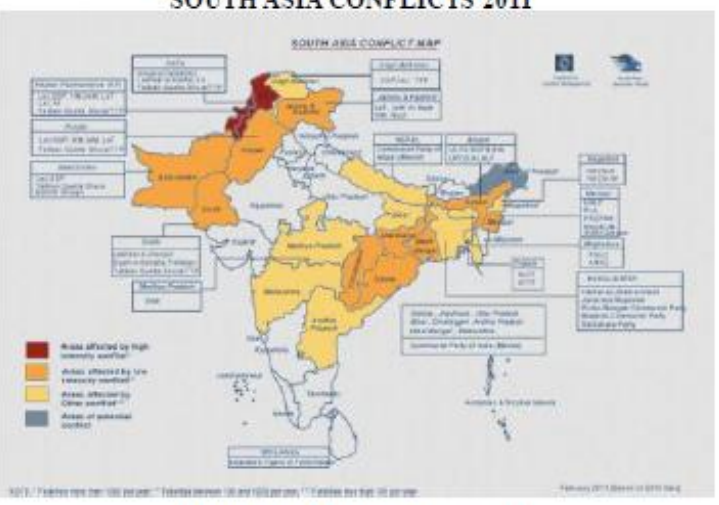

SOUTH ASIA CONFLICTS 2015

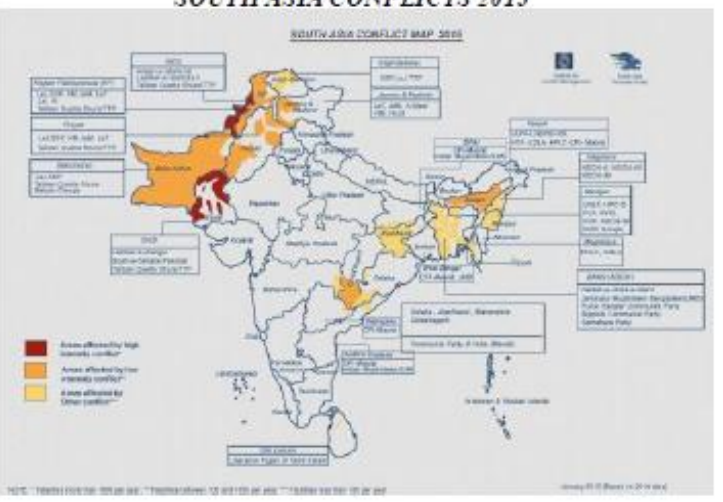

Map3: South Asian Conflicts In 2011,12,14,15

Conflicts in South Asia, or for that matter in most of the other parts of the world, can be broadly put in four categories, namely (i) those imposed and escalated by the global political, strategic and developmental dynamics, including the role of great powers; (ii) those inherited and strategically induced in inter-state engagements; (iii) those precipitated and nurtured by the internal political turbulence, socio-cultural fault-lines and developmental distortions; and (iv) those that are caused and covered by the non-state actors. The first category includes conflicts inflicted by the forces and factors from outside the region.( For a discussion of the negative aspects of globalisation, including on South Asia, see, George Heine \& Ramesh Thakur (Ed.), The Dark Side of Globalization, United Nations University Press, Tokyo, New York, Paris, 2011.) 
It is acknowledged in South Asia that one of the greatest obstacles to the success of regional cooperation under South Asian Association for Regional Cooperation (SAARC) has been the conflict between India and Pakistan. As bilateral trade channels are being activated between India and Pakistan, it is hoped that regional trade will grow to the advantage of all the member countries. Conflict and regional rivalry between India and Pakistan is also obstructing the prospects of their mutual cooperation with Afghanistan, which, if facilitated, can in turn help both Pakistan and Afghanistan fight their internal insurgencies better.26(26 See Shahid Javed Burki, South Asia in the New World Order: The Role of Regional Cooperation, Routledge, New York, London, 2011.)

Most of the cross-country literature on the incidence of civil war shows that poor countries are at greater risk of internal conflict (Collier and Hoeffler, 2004; Fearon and Laitin, 2003). The latter study also finds that geographical conditions which favor insurgency, such as the presence of forest cover, is significantly associated with the incidence of conflict. Do and Iyer (2007) found similar results in an analysis of conflict intensity across the districts of Nepal. Many policymakers cite the lack of economic opportunities, and specifically the extent of landlessness, as a primary determinant of the Naxalite conflict in India.19 (19 "A large proportion of the recruits to extremist groups come from deprived or marginalized backgrounds or from regions which somehow seem disaffected by the vibrant growth in many other parts of the country."

The economic and geographic circumstances as well as social divisions are often cited as a driver of conflict. For instance, the separatist movement in Sri Lanka began with the demands of ethnic Tamils for greater autonomy. Similarly, the Maoist rebels in Nepal often claim to be fighting on behalf of marginalized sections of society, such as members of the lower castes. India's northeastern states, which are the scene of long-running separatist movements, are also socially and ethnically different from the majority of the states in India. I examine some correlations between the incidence of conflict and the geographic, economic and societal characteristics of South Asian regions. Table 12 summarizes the correlations of the number of incidents and number of fatalities in terrorist incidents with demographic variables (population density, urbanization, literacy rates) and economic variables (\% of population in poverty). Consistent with the idea that economic backwardness matters, we find a negative correlation between conflict intensity and measures of literacy and urbanization; however, we do not see the expected positive correlation with poverty (Table 12, Panel A).

South Asia Fatalities 2010-2017

\begin{tabular}{|l|l|l|l|l|l|l|}
\hline Years & Civilians & $\begin{array}{l}\text { SFs(Security } \\
\text { Forces) }\end{array}$ & Terrorists & Total & $\begin{array}{l}\text { Population } \\
\text { (Crore) }\end{array}$ & $\begin{array}{l}\text { Number of Poor } \\
\text { (Millions) }\end{array}$ \\
\hline 2010 & 2571 & 844 & 6016 & 9431 & 170.2 & 400.3 \\
\hline 2011 & 3173 & 962 & 3284 & 7419 & 172.7 & 327.9 \\
\hline 2012 & 3270 & 871 & 2902 & 7043 & 175.1 & 293.3 \\
\hline 2013 & 3536 & 887 & 2244 & 6667 & 177.5 & 256.2 \\
\hline 2014 & 2217 & 703 & 3631 & 6551 & 177.9 & 244.3 \\
\hline 2015 & 1144 & 496 & 2837 & 4477 & 182.2 & 239.2 \\
\hline 2016 & 854 & 476 & 1505 & 2835 & 184.6 & 233.1 \\
\hline 2017 & 533 & 249 & 663 & 1445 & 187.0 & 227.4 \\
\hline
\end{tabular}

* Data till August 6, 2017

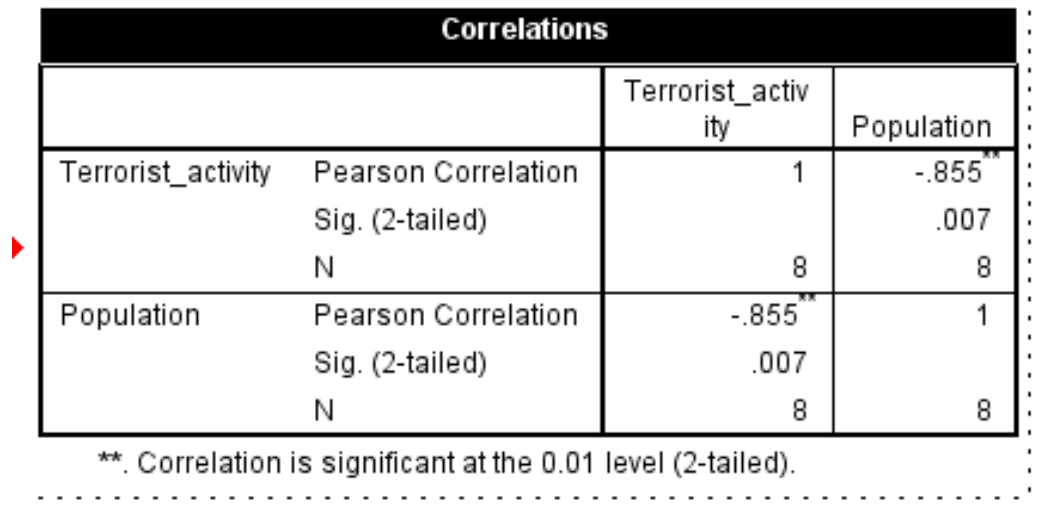

Correlation between Number of Terrorist incidences (2010-2017) and Population in South Asia 


\begin{tabular}{|c|c|c|c|}
\hline \multicolumn{4}{|c|}{ Correlations } \\
\hline & & $\begin{array}{c}\begin{array}{c}\text { Terrorist_activ } \\
\text { ity }\end{array} \\
\end{array}$ & $\begin{array}{l}\text { Poor_populati } \\
\text { on }\end{array}$ \\
\hline \multirow[t]{3}{*}{ Terrorist_activity } & Pearson Correlation & 1 & $.846^{\prime \prime}$ \\
\hline & Sig. (2-tailed) & & .008 \\
\hline & $\mathrm{N}$ & 8 & 8 \\
\hline \multirow[t]{3}{*}{ Poor_population } & Pearson Correlation & $.846^{\prime \prime \prime}$ & 1 \\
\hline & Sig. (2-tailed) & .008 & \\
\hline & $N$ & 8 & 8 \\
\hline
\end{tabular}

**. Correlation is significant at the 0.01 level (2-tailed).

Correlation between Number of Terrorist incidences (2010-2017) and Number of Poor Population in South Asia

\begin{tabular}{|c|c|c|c|}
\hline \multicolumn{4}{|c|}{ Variables Entered/Removed ${ }^{a}$} \\
\hline Model & $\begin{array}{c}\text { Variables } \\
\text { Entered } \\
\end{array}$ & $\begin{array}{l}\text { Variables } \\
\text { Removed }\end{array}$ & Method \\
\hline 1 & $\begin{array}{l}\text { Poor_populati } \\
\text { on }{ }^{b}\end{array}$ & & Enter \\
\hline
\end{tabular}

a. Dependent Variable: Terrorist_activity

b. All requested variables entered.

\section{Model Summary}

\begin{tabular}{|l|l|r|r|r|}
\hline Model & R & R Square & $\begin{array}{c}\text { Adjusted R } \\
\text { Square }\end{array}$ & $\begin{array}{c}\text { Std. Error of } \\
\text { the Estimate }\end{array}$ \\
\hline 1 & $.846^{\mathrm{a}}$ & .716 & .668 & 917.498 \\
\hline
\end{tabular}

a. Predictors: (Constant), Poor_population

ANOVA $^{\text {a }}$

\begin{tabular}{|c|c|c|c|c|c|c|}
\hline Model & & $\begin{array}{l}\text { Sum of } \\
\text { Squares }\end{array}$ & df & Mean Square & $\mathrm{F}$ & Sig. \\
\hline \multirow[t]{3}{*}{1} & Regression & 12723220.35 & 1 & 12723220.35 & 15.114 & $.008^{b}$ \\
\hline & Residual & 5050815.148 & 6 & 841802.525 & & \\
\hline & Total & 17774035.50 & 7 & & & \\
\hline
\end{tabular}

a. Dependent Variable: Terrorist_activity

b. Predictors: (Constant), Poor_population

Regression, Anova and Coefficient of Coorelation between Number of Terrorist incidences (2010-2017) and Number of Poor Population in South Asia

\begin{tabular}{|c|c|c|c|c|c|c|}
\hline \multicolumn{7}{|c|}{ Coefficients $^{a}$} \\
\hline \multirow{2}{*}{\multicolumn{2}{|c|}{ Model }} & \multicolumn{2}{|c|}{ Unstandardized Coefficients } & $\begin{array}{l}\text { Standardized } \\
\text { Coefficients }\end{array}$ & \multirow[b]{2}{*}{$t$} & \multirow[b]{2}{*}{ Sig. } \\
\hline & & $B$ & Std. Error & Beta & & \\
\hline \multirow[t]{2}{*}{1} & (Constant) & -3333.513 & 1632.157 & & -2.042 & .087 \\
\hline & Poor_population & 22.393 & 5.760 & .846 & 3.888 & .008 \\
\hline
\end{tabular}

a. Dependent Variable: Terrorist_activity

\section{THE SECURITY APPROACH}

South Asian countries have therefore adopted many strategies to augment the effectiveness of the police forces to deal with internal conflict: devoting more resources to existing police forces, raising local militias, and calling in the armed forces.

In India, the security manpower has been increased by deploying 33 battalions of Central Paramilitary Forces to conflict-affected states, and by sanctioning the recruitment of a further 32 battalions of India Reserve forces. The central government also disbursed Rs 5 billion to states affected by Naxalite violence in 2005-06 to reimburse states for their expenditures on training, ammunition, 
communications, transport, rehabilitation of surrendered Naxalites, ex-gratia payments to families of Naxalite victims and insurance for police personnel (Joseph, 2007, p 94). More controversially, the state of Chhattisgarh has helped local militias like the Salwa Judum in Dantewada district, which were organized as self-defense groups against Naxalite violence.

The record of such informal militias has been mixed in the other South Asian countries as well. In Sri Lanka, some Tamil groups (such as the Razeek group of the formerly militant EPRLF) have been used as paramilitary forces by the Sri Lanka Army.

\subsection{The Military Approach}

In extreme cases, when police forces turn out to be insufficient, the armed forces are called in to deal with the insurgency. In most cases, this has not proved to be a successful strategy in South Asia. The Maoists went on to win the largest number of seats in the Constituent Assembly elections in April 2008. The Sri Lankan Army has battled the LTTE for more than two decades without any lasting solution; only in early 2009 was the army in a position to conclusively defeat the rebels.

In 1984, the Indian army stormed the Golden Temple in Amritsar in a major operation against Sikh separatists. This perceived desecration of the Sikh religion's holiest shrine led to heightened insurgency in Punjab state for the next eight years, before tough police action finally brought the Situation under control.

In Pakistan, the use of armed forces has had some successes to its credit. For instance, the local insurgency in Balochistan has been considerably scaled down after the assassination of Nawab Akbar Bugti by the military in 2006

\subsection{The Political Approach}

The peace talks between the government of Andhra Pradesh and the People's War Group (PWG) in 2004 were undermined by the fact that other states were conducting counter-terrorism raids against the PWG at the same time. Similarly, the proposed talks with the ULFA in Assam have floundered because the ULFA wanted the sovereignty of Assam to be on the agenda, which the Indian government did not agree to. In contrast, the limited autonomy desired by the Bodo militant groups was discussed and ultimately granted.

\subsection{The Economic Approach}

This is consistent with the view of economic backwardness as one of the root causes of conflict. The government of India has designated all the northeastern states as "Special Category" states for purposes of funding: all of these states received more than Rs. 1000 per capita from the Planning Commission in 2003-04, compared to the nationwide average of Rs. 438. Are such economically oriented incentives effective in reducing conflict? In general, it is hard to quantify the impact of such measures on the intensity of conflict, partly because of the paucity of data on exact amounts allocated at the very local level.

\subsection{Regional Cooperation in Conflict Management}

The Maoists in Nepal had formed close links with the Maoist movements in India. Many separatist groups in India's northeastern states have camps in neighboring countries like Bangladesh and Bhutan. The Taliban in Afghanistan obtain significant support from Pakistan's border areas. The LTTE and other Tamil separatist groups in Sri Lanka have traditionally enjoyed support from Tamil populations in India and abroad. In such a context, regional cooperation is an essential part of any counter-insurgency strategy. India had a hands-off policy towards the conflict in Nepal as well. India did provide material assistance, such as helicopters, to the Royal Nepal Army. But there was no direct intervention by the Indian government such as facilitating negotiations with the rebels, or sending in peace keeping forces.

\section{Conclusions}

The increasing trend in internal conflict in South Asia in the new millennium. My analysis has highlighted that poverty is statistically and economically significant in explaining the spatial variation in conflict intensity in the post- 2010 period. However, economically lagging regions did not always have higher conflict in previous decades, and there is no corresponding increase in other crimes or 
violent incidents not aimed at spreading terror. These facts suggest that a change in the global environment after 2001 may also have played a role in the observed trends.

Policymakers in South Asia have tried various policies to reduce conflict. The most common approach to deal with insurgencies, terrorism, or internal violence is to use the police forces to establish law and order in the affected areas. The police forces in South Asian countries, however, tend to be understaffed and underequipped. In cases where police forces are insufficient, the armed forces are called in to deal with the insurgency. In most cases, this has not been a successful strategy. Even when these measures are successful in defeating the insurgents, as in Sri Lanka, the human cost associated with military operations is very high.

\section{REFERENCE}

[1] Sahni, Ajai (2007) 'Andhra Pradesh: The state advances, the Maoists retreat.' South Asia Intelligence Review South Asia Terrorism Portal (2008a) 'Pakistan Assessment 2008.' http://satp.org/satporgtp/ countries/pakistan/index.htm, accessed August 2008 (2008b) 'Sri Lanka Assessment 2008.' http://satp. org/satporgtp/countries/shrilanka/ index.html,accessed August 11, 2008

[2] Varshney, Ashutosh (2002) Ethnic Conflict and Civic Life: Hindus and Muslims in India (New Haven: Yale University Press)

[3] Government of India (2009) 'Mumbai Terrorist Attack (November 26-29, 2008).' Dossier provided to Government of Pakistan, January 5, 2009; http://www.hindu. com/nic/dossier.htm, accessed January 23, 2009

[4] (3 A. Bailes, John Gooneratne, Mavara Inayat, Jamshed Ayaz Khan and Swaran Singh (2007). 'Regionalism and Security building', Regionalism in South Asian Diplomacy, SIPRI Policy Paper No. 15, 2007 Stockhol. International Peace Research Institute, Sweden).

[5] (1 Speech to the Conference of Chief Ministers on Internal Security, December 20, 2007). http://www.satp.org/satprogtp/countries/india/document/papers/20071220pms peech.htm, accessed March 14, 2008.) (2 http://satp.org/satporgtp/sair/Archives/6 10. htm, accesse August 7, 2008).

[6] In Pakistan, the usual criminal codes and police jurisdiction do not apply in the FATA region, on the border between Pakistan and Afghanistan. The Pakistani government therefore signed a peace deal with the local tribal leaders ("maliks"), who are in charge of local administration.

[7] Razeek was assassinated by a suicide bomber in 1999. http://www.hinduonnet.com/fline/ fl1613/ 16130550.htm

[8] FATA is governed by the Frontier Crimes Regulations, originally framed by the British in 1901. Universal adult suffrage was introduced to FATA only in 1996.)

[9] (23 South Asia Terrorism Portal, 2008a).

[10] Fiscal Profiles of States compiled by Finance Commission, Ministry of Statistics and Programme Implementation.).

[11] (South Asia Terrorism Portal, 2008b.)

Citation: Dr. Sunita Pachori. "Conflicts in South Asia - Challenges to SAARC Regionalism”. International Journal of Research in Geography. vol 5, no. 1, 2019, pp. 34-41. doi: http://dx.doi.org/10.20431/2454-8685. 0501004.

Copyright: (C) 2019 Authors. This is an open-access article distributed under the terms of the Creative Commons Attribution License, which permits unrestricted use, distribution, and reproduction in any medium, provided the original author and source are credited. 